\title{
Comparison of exhaust emission from Euro 3 and Euro 6 motor vehicles fueled with petrol and LPG based on real driving conditions
}

\begin{abstract}
Constantly increasing requirements regarding emission limits for harmful exhaust components force vehicle manufacturers to improve the construction of vehicle engines as well as exhaust gas cleaning systems. In addition to modifications in the field of technology of motor vehicles themselves, it is also important to study the impact of alternatives to petrol or diesel fuels. One of the most popular fossil fuel is liquid petroleum gas. In the paper, the results of comparative studies on the emission of harmful exhaust components of vehicles meeting the Euro 3 and Euro 6 standards in the field of petrol and LPG fuel use are presented. Emission measurement was performed using a portable emission measurement system from Horiba OBS-2200 under real traffic conditions. The presented results show the differences between the tested vehicles and the fuels used.
\end{abstract}

Key words: emission, PEMS, fuel, LPG, RDE

\section{Introduction}

In recent years, due to the constantly growing requirements regarding the emission policy, which must be met by car manufacturers, there has been a dynamic development of the construction of internal combustion engines as well as catalytic systems [3]. The main legislative objectives of the European Union concern the reduction of harmful effects on the surrounding environment, both on human health and climate change. The automotive sector is the main source of a different variety of air pollutants, eg hydrocarbons, nitrogen oxides, carbon monoxide, particulate matter as well as greenhouse gases, which include primarily carbon dioxide [2, 4-6, 8].

One of the alternative renewable fuels that have lower emissions of toxic compounds is LPG. LPG is acquired as a naturally occurring product of the natural gas extraction process or as an automatic result of the oil refining production process. LPG meets all four key objectives set by the EU in its guidelines for trans-European energy networks [7]. LPG is petroleum derived colourless gas, consists of propane or butane or from mixtures of both. In everyday usage different mixtures are used depending on the climatic nature of every region [11]. This gas is also characterized by a low price, which makes its popularity grows as an alternative to petrol and diesel.

The aim of the study was to determine the emission value of harmful exhaust components $\left(\mathrm{CO}_{2}, \mathrm{THC}, \mathrm{NO}_{\mathrm{x}}, \mathrm{CO}\right)$ for vehicles meeting the Euro 3 and Euro 6 standards in the scope of petrol and LPG fueling. The emission measurement was made by using a portable emission measurement system for the selected route, which included the urban, rural and motorway part.

\section{The methodology of the study}

The road selected for testing, including the urban, rural and motorway part, is shown in Fig. 1. The route was $40 \mathrm{~km}$ long, while the rides were made in June 2018.

The PEMS Horiba OBS-2200 system was used to measure road emissions, the specifications of which are presented in Table 1. PEMS can be installed in the boot of the tested vehicle, while the measuring sensors with a flow meter are connected to the outlet pipe [12]. The exhaust gas pipe must be heated to $190^{\circ} \mathrm{C}$ to avoid condensation of hydrocarbons. In addition, ambient temperature and humidity sensors, as well as a GPS transmitter, are connected to the system [3]. In order to get a full picture of the impact of the engine operation on the generated emission, the OBDII interface $[5,13,14]$ can be connected to the ECU of the vehicle. The RDE test was started by comparing the measurement from the PEMS system with the AMA i60 stationary exhaust gas analysis system. Initial tests were carried out on a chassis dynamometer built in a climate chamber on a passenger car. The test results showed that differences in the emission values of pollutants measured using the PEMS and AMAi60 systems, were within the permissible deviations. Therefore, further measurements of emissions in real traffic conditions can be considered as correct.

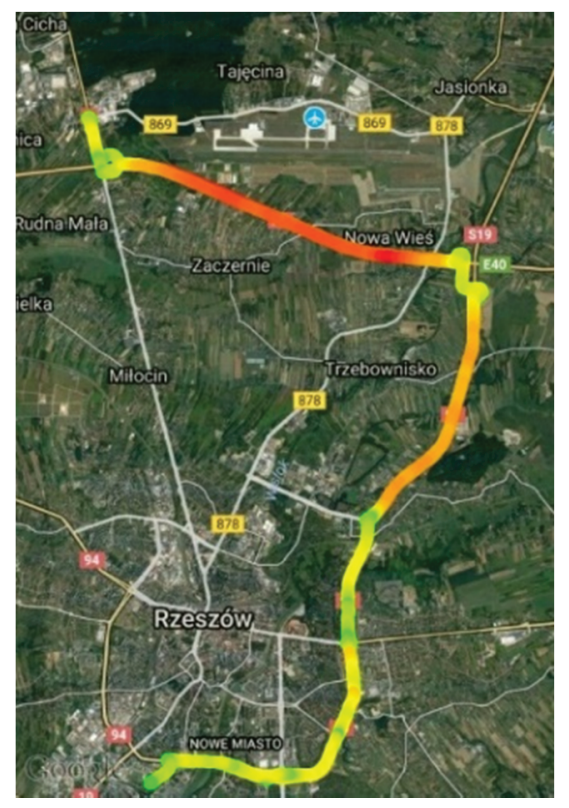

Fig, 1. Map with the selected stretch of road test 
Table. 1. Selected technical parameters of the PEMS Horiba OBS-2200 system

\begin{tabular}{|c|c|c|}
\hline Parameter & Measurement method & Accuracy \\
\hline $\begin{array}{l}\text { The concen- } \\
\text { tration of } \\
\text { exhaust } \\
\text { components: } \\
\text { CO }\end{array}$ & $\begin{array}{l}\text { NDIR - non-dispersive } \\
\text { (infrared), range } 0-10 \%\end{array}$ & $\pm 2.5 \%$ \\
\hline $\mathrm{CO}_{2}$ & $\begin{array}{l}\text { NDIR - non-dispersive } \\
\text { (infrared), range } 0-10 \%\end{array}$ & $\pm 2.5 \%$ \\
\hline THC & $\begin{array}{l}\text { FID - flame ionization, } \\
\text { range } 0-10000 \mathrm{ppm}\end{array}$ & $\pm 2.5 \%$ \\
\hline $\mathrm{NO}_{\mathrm{x}}$ & $\begin{array}{l}\text { CLD - chemilumines- } \\
\text { cence, range from } \\
0-100 \text { to } 0-3000 \mathrm{ppm}\end{array}$ & $\pm 2.5 \%$ \\
\hline $\begin{array}{l}\text { Sampling } \\
\text { frequency }\end{array}$ & $0.1 \mathrm{~Hz}$ & \\
\hline $\begin{array}{l}\text { The heating } \\
\text { time of the } \\
\text { analyzers }\end{array}$ & Up to 1 hour & - \\
\hline Gas flow & Mass flow rate & $\begin{array}{l}\text { In the range } \\
\text { of } \pm 1.5 \% \text { of } \\
\text { full scale or } \\
\text { within } \\
\pm 2.5 \% \text { of } \\
\text { readings }\end{array}$ \\
\hline
\end{tabular}

Vehicles used for road emission tests are shown in Fig. 2. The vehicle fulfilling the Euro 3 standard is characterized by a $1991 \mathrm{~cm}^{3}$ engine, it has manual transmissions, an MPI power system and a TWC catalytic system, while a vehicle meeting the Euro 6 standard has an $1149 \mathrm{~cm}^{3}$ engine, while the other described parameters are the same as the predecessor, both vehicles are fueled with petrol as well as LPG. On the day of testing, the Euro 3 car had a mileage of $260,000 \mathrm{~km}$, while the Euro 6 was 42,000 km.

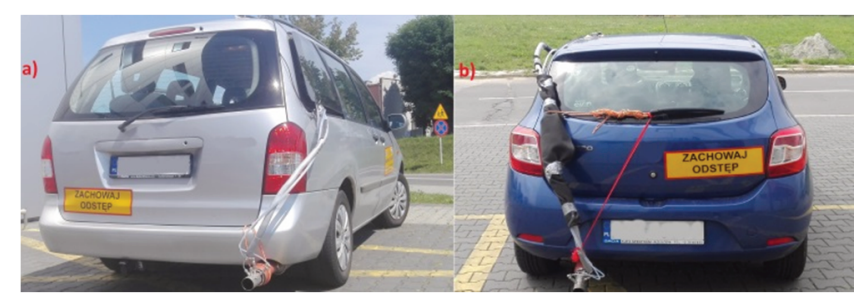

Fig. 2. Cars used for road tests with installed PEMS: a) Euro 3, b) Euro 6

\section{The road tests results}

All 4 tests lasted for a similar time and amounted to around $2500 \mathrm{~s}$, only the travel time for a Euro 3 vehicle fueled with gasoline in the charts is $3000 \mathrm{~s}$, because for illustrative purposes, emissions during cold-start mode were not excluded. The graphs of specific distance emission at the end of the work for all tested harmful exhaust components are already for the engine warmed up. Fig. 3-6 shows the emission intensity of $\mathrm{CO}_{2}$ for the tested vehicles fueled with petrol and LPG.

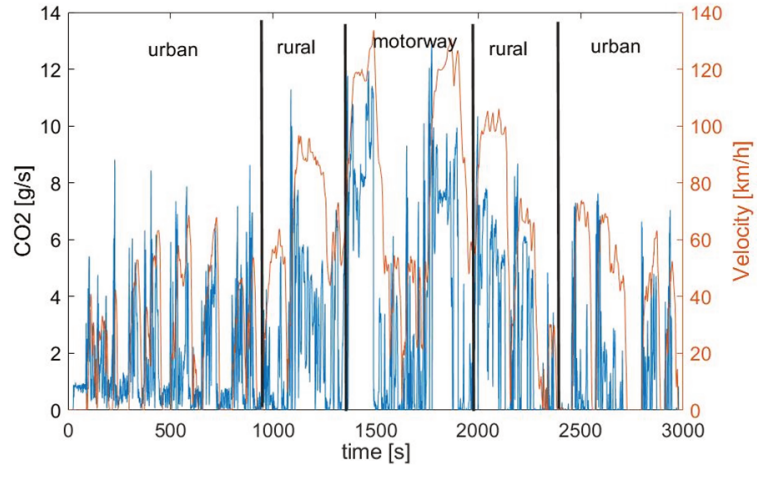

Fig, 3. Emission intensity of $\mathrm{CO}_{2}$ for Euro 3 petrol fuelled vehicle

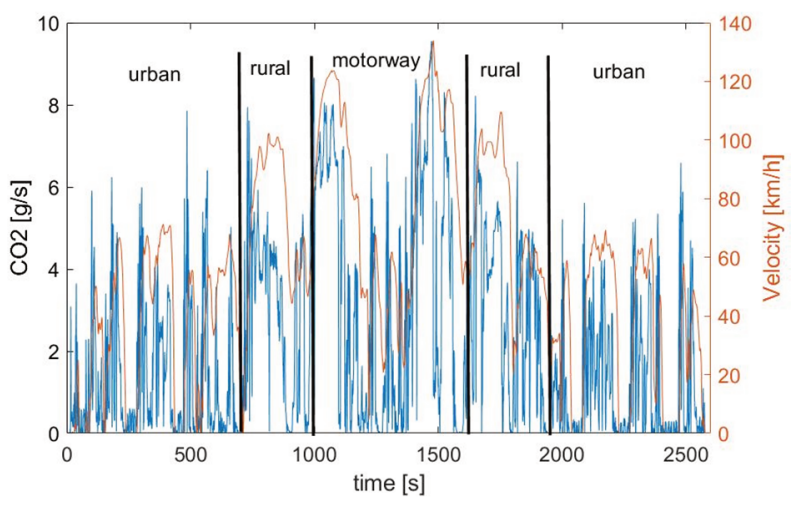

Fig, 4. Emission intensity of $\mathrm{CO}_{2}$ for Euro 3 LPG fuelled vehicle

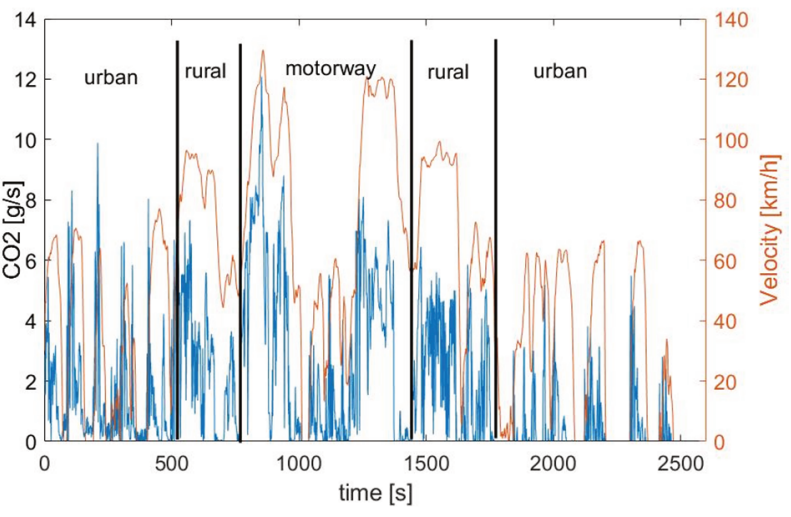

Fig, 5. Emission intensity of $\mathrm{CO}_{2}$ for Euro 6 petrol fuelled vehicle

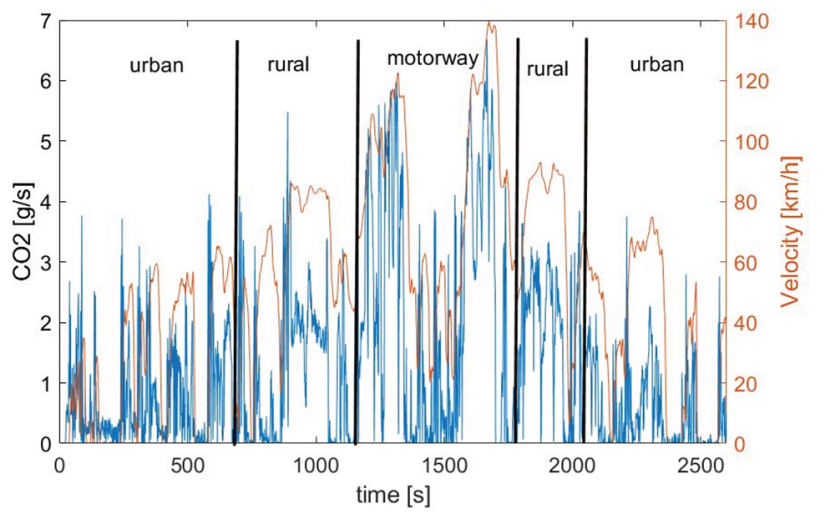

Fig, 6. Emission intensity of $\mathrm{CO}_{2}$ for Euro 6 LPG fuelled vehicle 
Based on Fig. 3-6, it is visible that:

- in relation to Fig. 3, which also has data regarding the cold-start (first $250 \mathrm{~s}$ ), it can be noticed that the $\mathrm{CO}_{2}$ emission intensity and its increase as a result of the engine's operating temperature is not so significant compared to other exhaust components, e.g. THC, $\mathrm{NO}_{\mathrm{x}}$,

- the highest $\mathrm{CO}_{2}$ emission intensity occurs while vehicle speed increase and sudden acceleration,

- the highest $\mathrm{CO}_{2}$ emission intensity values for all researched cases are for the motorway section, this is related to high speeds on such sections of roads,

- $\mathrm{CO}_{2}$ emissions intensity for tested LPG-powered vehicles are lower compared to petrol: for Euro 3 vehicle approx. 15\%, and for Euro 6 approx. $18 \%$.

Figures 7-10 show the emission of THC for both vehicles tested, fueled with LPG and petrol. As in the previous case, the graph for a petrol-powered Euro 3 vehicle also contains data on the engine's heating phase. Based on the THC emission graphs, it can be observed that:

- the largest part of THC emissions is related to the coldstart of the engine and it accounts for about $66 \%$ of the total emissions for the whole ride,

- for the Euro 3 vehicle fueled with LPG, the highest increase in THC emissions occurs for the urban part, while the subsequent parts are characterized by a similarly steady upward trend in emissions,

- for the Euro 6 vehicle fueled both by petrol and LPG, the largest increase in THC emissions occurs for the motorway part and it is the majority of the emission generated during the travel along the test route,

- THC emission for both the Euro 6 and Euro 3 vehicles is lower for LPG than for petrol.

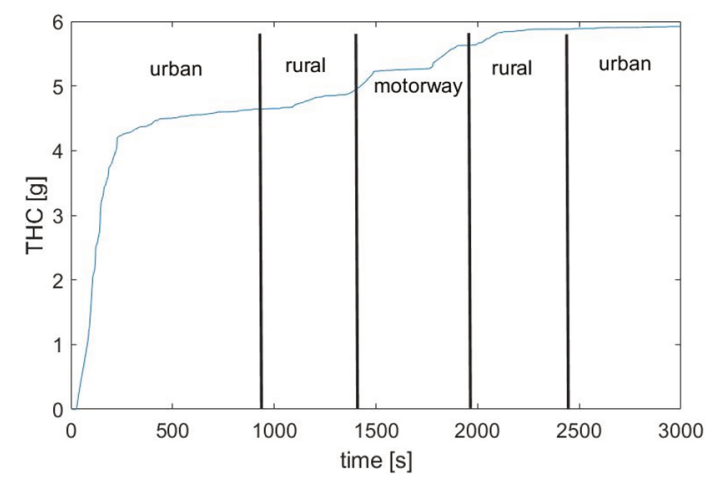

Fig, 7. Emission of THC for Euro 3 petrol fuelled vehicle

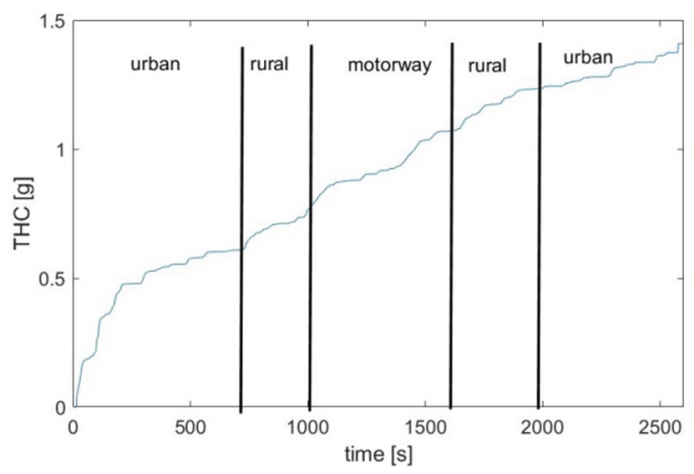

Fig, 8. Emission of THC for Euro 3 LPG fuelled vehicle

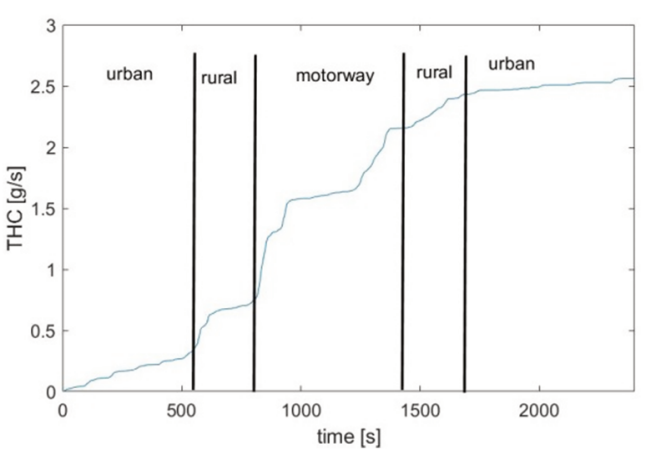

Fig, 9. Emission of THC for Euro 6 petrol fuelled vehicle

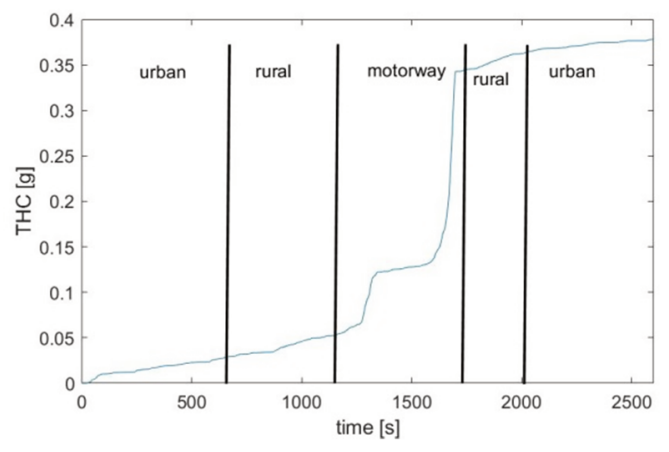

Fig, 10. Emission of THC for Euro 6 LPG fuelled vehicle

Graphs of $\mathrm{NO}_{\mathrm{x}}$ emissions intensity as a function of acceleration and velocity are presented in Fig. 11-14.

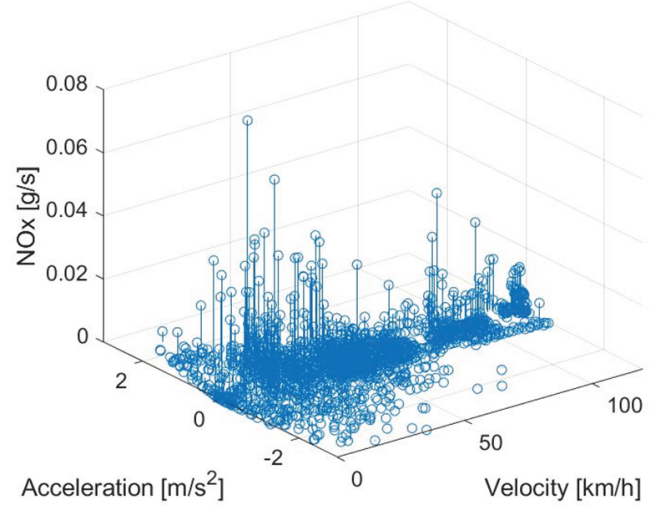

Fig, 11. Correlation between $\mathrm{NO}_{\mathrm{x}}$ emission intensity and velocity and acceleration of Euro 3 petrol fuelled vehicle

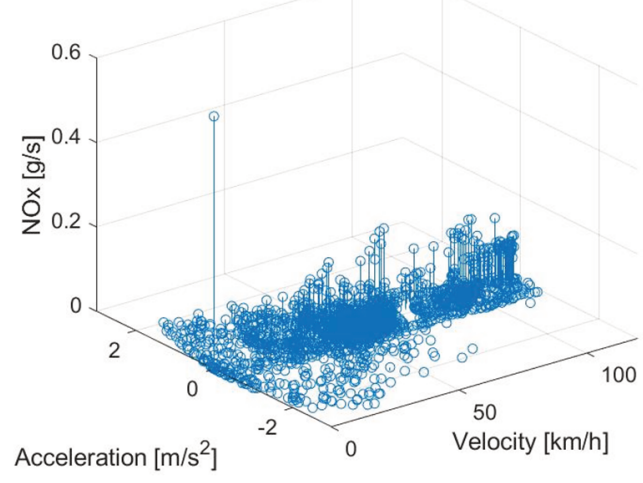

Fig, 12. Correlation between $\mathrm{NO}_{\mathrm{x}}$ emission intensity and velocity and acceleration of Euro 3 LPG fuelled vehicle 


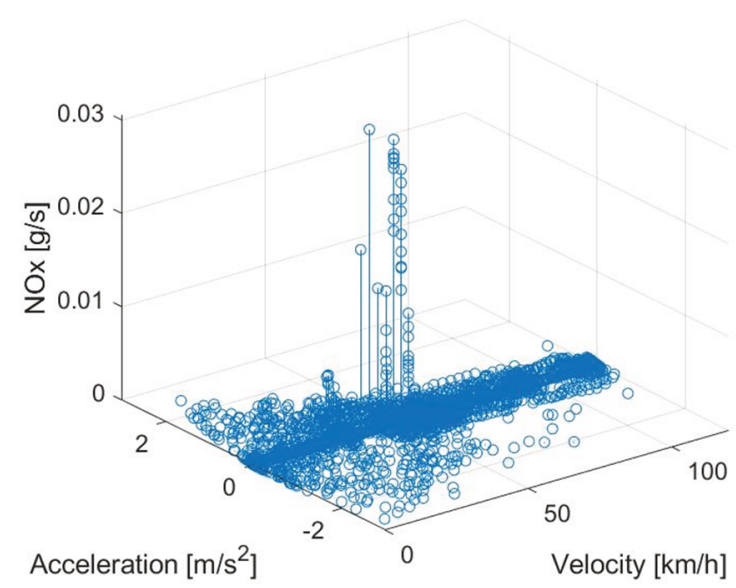

Fig, 13. Correlation between $\mathrm{NO}_{\mathrm{x}}$ emission intensity and velocity and acceleration of Euro 6 petrol fuelled vehicle

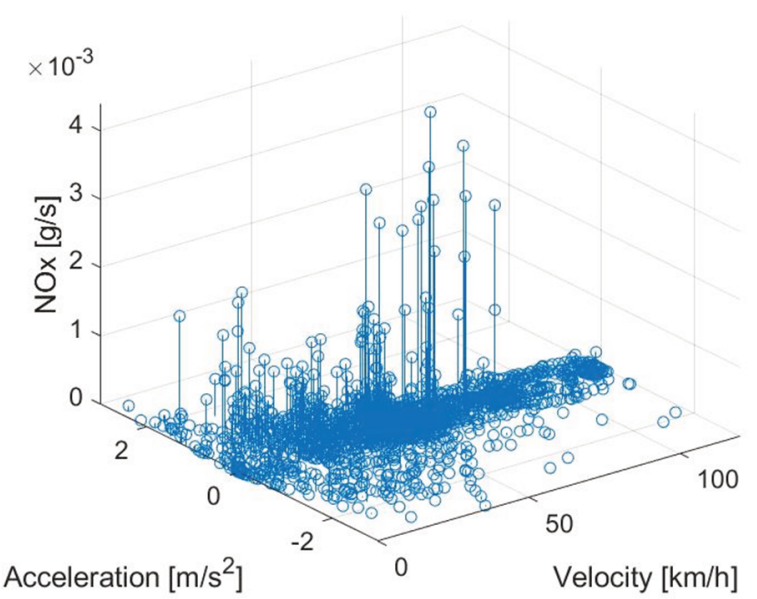

Fig, 14. Correlation between $\mathrm{NO}_{\mathrm{x}}$ emission intensity and velocity and acceleration of Euro 6 LPG fuelled vehicle

Based on the $\mathrm{NO}_{\mathrm{x}}$ emission intensity graphs shown in Figs 11-14, it can be seen, that:

- the largest $\mathrm{NO}_{\mathrm{x}}$ emission intensity for petrol fueled Euro 3 vehicle occurs in the low speed range and temporarily during acceleration of speeds higher than $80 \mathrm{~km} / \mathrm{h}$, while for LPG higher $\mathrm{NO}_{\mathrm{x}}$ emissions intensity occur for speeds higher than $50 \mathrm{~km} / \mathrm{h}$ during acceleration of the vehicle,

- for the Euro 6 vehicle, the $\mathrm{NO}_{\mathrm{x}}$ emission intensity for petrol shows only temporary higher values at speeds of around $50 \mathrm{~km} / \mathrm{h}$, while in the range of other speeds/ accelerations it is relatively low; for LPG, higher $\mathrm{NO}_{\mathrm{x}}$ emission intensity values occur in a wider range of speed and acceleration of the vehicle.

Figs 15-18 presents specific distance emission for harmful emission components. The results for $\mathrm{NO}_{\mathrm{x}}, \mathrm{CO}$ and THC were compiled to emission limits valid for a given vehicle emission standard.

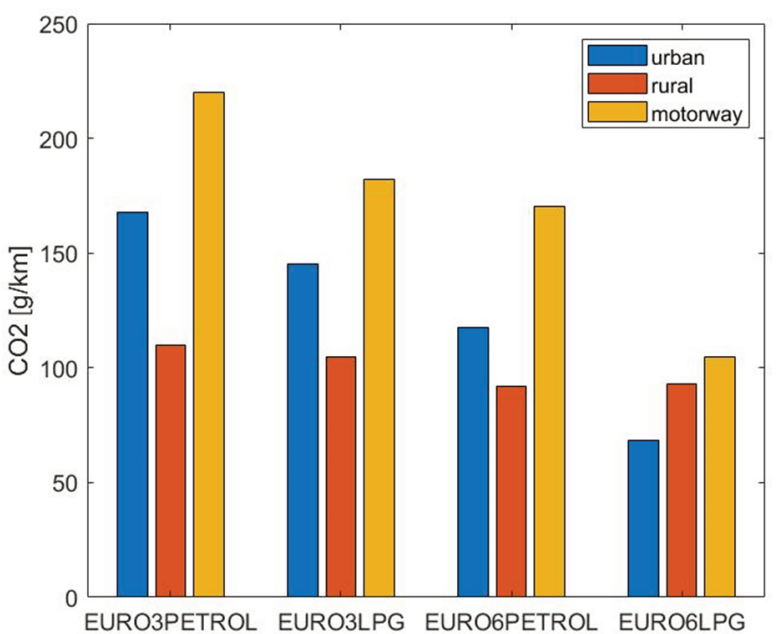

Fig, 15. Specific distance emission of $\mathrm{CO}_{2}$ for selected parts of road tests

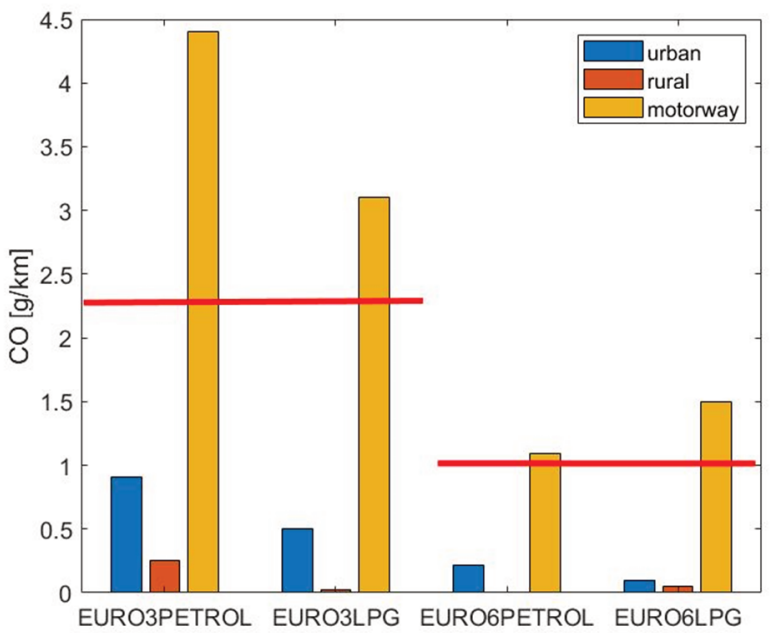

Fig, 16. Specific distance emission of CO for selected parts of road tests (red line is emission limit)

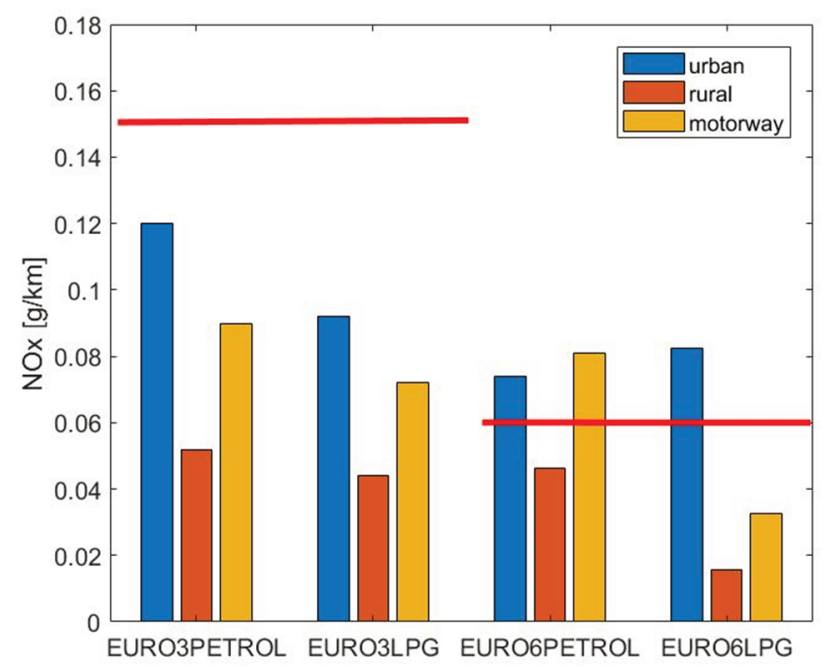

Fig, 17. Specific distance emission of $\mathrm{NO}_{\mathrm{x}}$ for selected parts of road tests (red line is emission limit) 


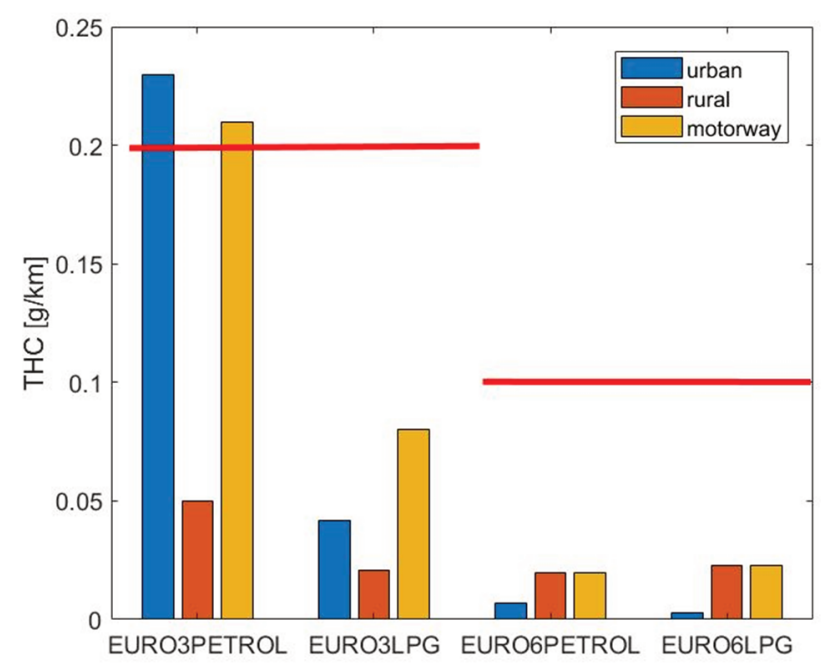

Fig, 18. Specific distance emission of THC for selected parts of road tests (red line is emission limit)

Analyzing the data contained in Fig. 15-18, it can be noted that:

- for all trips the highest $\mathrm{CO}_{2}$ emission values occurred for the motorway section, this is related to the highest fuel consumption by the tested vehicles at high speed,

- exceeding the Euro 3 and Euro 6 standards limits occurred for $\mathrm{CO}$ in the area of passage through the motorway section, the remaining parts of the route and specific distance emissions emitted on them are relatively low,

- exceeding the Euro standard limits for $\mathrm{NO}_{\mathrm{x}}$ occurred for the Euro 6 vehicle in the following parts of the test: for petrol - urban, motorway, and for LPG - urban,

- THC specific distance emission reaches the highest values for the Euro 3 vehicle in the petrol range, exceeding the limits for this road test takes place in the urban and motorway part.

\section{Conclusions}

The results of comparative emission tests for vehicles complying with the Euro 3 and Euro 6 standards fuelled by petrol and LPG presented in the work indicate:
- lower $\mathrm{CO}_{2}$ specific distance emissions for the Euro 6 vehicle compared to Euro 3 for all road parts, for petrol for the urban part by approx. 25\%, rural for approx. $22 \%$, motorway approx. $26 \%$, and for LPG for part of the city about $47 \%$, rural about $20 \%$ and motorway about $42 \%$,

- much lower CO specific distance emission of the Euro 6 vehicle in relation to Euro 3, mainly in the aspect of motorway section, which is approximately 4 times smaller for petrol, and 2 times for LPG,

- lower $\mathrm{NO}_{\mathrm{x}}$ specific distance emission for the Euro 6 vehicle compared to Euro 3, mainly in the aspect of rural and motorway parts for LPG fueling,

- several times lower THC specific distance emission for both petrol and LPG, for Euro 6 vehicle in relation to Euro 3.

In most cases, the parts of the test within one type of vehicle show the advantage of LPG in relation to petrol in terms of emission of harmful exhaust components.

The presented comparative results of the tested vehicles are indicative and cannot be taken unequivocally, as both vehicles have different mass as well as the used drive unit and the catalytic system. Valuable results can be those within one vehicle in the range of comparison of petrol to LPG.

Certainly, the emission data provided depends also on the driver's driving style and prevailing traffic conditions, which may lead to certain limitations and inaccuracies, but it is important to conduct this type of research because it is crucial to know the amount of emission taking place in the real driving. In fact, every road test is unique. These data are valuable especially in the aspect of learning about the real road emissions, as well as provide the possibility of later use for the development of various types of emission models of fumes pollution $[1,9,10]$.

Based on the emission results it can be said, that the LPG represents a good fuel alternative for petrol and therefore it must be taken into consideration in the future of large-scale personal transport.

\section{Nomenclature}

LPG liquefied petroleum gas

$\mathrm{CO}_{2}$ carbon dioxide

THC total hydrocarbon

$\mathrm{NO}_{\mathrm{x}}$ nitrogen oxides
$\mathrm{CO}$ carbon monoxide

$\mathrm{RDE}$ real driving emission

PEMS portable emission measurement system

MPI multi point injection

\section{Bibliography}

[1] AL ALAMI, Y.R. Application of traffic emission models to the estimation of local pollutant hotspots in South Kensington. 1st Civil and Environmental Engineering Student Conference Energy. 2012, 11, Imperial College London.

[2] BIELACZYC, P., MERKISZ, J., PIELECHA, J., WOODBURN, J. A Comparison of gaseous emissions from a hybrid vehicle and a non-hybrid vehicle under real driving conditions. SAE Technical Paper. 2018.
[3] JAWORSKI, A., LEJDA, K., MĄDZIEL, M., USTRZYCKI, A. Assessment of the emission of harmful car exhaust components in real traffic conditions. IOP Conf. Series: Materials Science and Engineering. 2018, 421, 042031.

[4] JAWORSKI, A., KUSZEWSKI, H., USTRZYCKI, A. et al. Analysis of the repeatability of exhaust pollutants emission research for cold and hot starts under controlled driving cycle conditions. Environmental Science and Pollution Research. 2018, 25, 17862-17877. 
[5] LIGTERINK, N.E. On-road determination of average Dutch driving behaviour for vehicle emissions. TNO Report 2016 $R$ 10188. 2016.

[6] MERKISZ, J., RYMANIAK, Ł. The assessment of vehicle exhaust emissions referred to $\mathrm{CO}_{2}$ based on the investigations of city buses under actual conditions of operation. Maintenance and Reliability. 2017, 19(4).

[7] PAPADOPOULOS, G., KERAMYDAS, C., NTZIACHRISTOS, L. et al. Emission factors for a taxi fleet operating on liquefied petroleum gas (LPG) as a function of speed and road slope. Front. Mech. Eng. 2018, 41.

[8] QUEROL, X., VIANA, M., ALASTUEY, A. et al. Source origin of trace elements in PM from regional background, urban and industrial sites of Spain. Atmos. Environ. 2007, 41.

[9] REXEIS, M., HAUSBERGER, S. Trend of vehicle emission levels until 2020 - prognosis based on current vehicle measurements and future emission legislation. Atmos. Environ. 2009, 43.

Artur Jaworski, DEng. - Faculty of Mechanical Engineering and Aeronautics, Rzeszów University of Technology.

e-mail:ajaworsk@prz.edu.pl

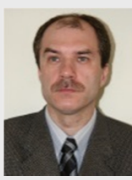

Prof. Kazimierz Lejda, DSc., DEng. - Faculty of Mechanical Engineering and Aeronautics, Rzeszów University of Technology.

e-mail: klejda@prz.edu.pl

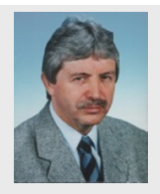

[10] SMIT, R., MCBROOM, J. Development of a new highresolution traffic emissions and fuel consumption model. Road Transp. Res. 2009, 18(4).

[11] TASTIC, T., POGOREVC, P., BRAJLIH, T. Gasoline and LPG exhaust emissions comparison. Advances in Production Engineering \& Management. 2011, 6.

[12] VARELLA, R., FARIA, M., MENDOZA-VILLAFUERTE, P. et al. Assessing the influence of boundary conditions, driving behavior and data analysis methods on real driving $\mathrm{CO}_{2}$ and $\mathrm{NO}_{\mathrm{x}}$ emissions. Science of the Total Environment. $2019,658$.

[13] VLACHOS, T. et al. The Euro 6 Real-Driving Emissions (RDE) procedure for light-duty vehicles. Effectiveness and practical aspects. 37th International Vienna Motor Symposium. 2016.

[14] WEISS, M. et al. On-road emissions of light-duty vehicles in Europe. Environ. Sci. Technol. 2011, 45.

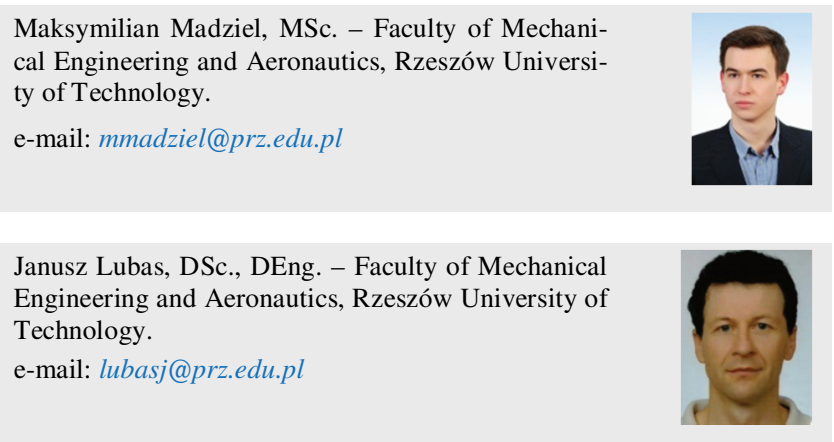
Engineering and Aeronautics, Rzeszów University of Technology 